\title{
The Global Reporting Initiative: What Value is Added?
}

W. Richard Sherman, J.D., LL.M., C.P.A., Saint Joseph's University, USA

\begin{abstract}
This paper explores the extent to which the Global Reporting Initiative G3 Reporting Framework adds value to the external reporting of a company's financial, environmental and social performance. This inquiry takes the form of analyzing the content of the published sustainability reports of well-known companies to compare and contrast the information communicated in these reports.
\end{abstract}

Keywords: Global Reporting Initiative; Triple Bottom Line; Sustainability Reporting

\section{INTRODUCTION}

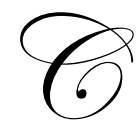

ritics of current corporate reporting practices abound. Particular criticism has been directed at the failure of annual reports or other regulatory files (e.g. 10Ks) to tell anything about a company's environmental and social performance. Triple bottom-line (TBL) reporting aims to remedy this shortcoming. However, initial efforts at TBL reporting were plagued by their lack of uniformity, consistency, and comparability in the information being presented. The Global Reporting Initiative (GRI) has attempted to fill this void by developing a detailed framework that is intended to create an analog to the generally accepted accounting principles (GAAP) approach to financial reporting.

The Global Reporting Initiative (GRI) was formed in 1997 by the Coalition for Environmentally Responsible Economies (CERES) in collaboration with the Tellus Institute. From its inception, the GRI has possessed a clear mission "to enhance responsible decision making by promoting international harmonization in reporting relevant and credible corporate economic, environmental, and social performance information" (GRI, 2002). To this end, the GRI has developed and published reporting guidelines based upon the broad TBL concept first developed by Elkington (1997; 1998). Since the issuance of its Exposure Draft of GRI Sustainability Reporting Guidelines in 1999 through to its publication of revised G3 Guidelines in October 2006, the GRI has attempted to provide a sound conceptual basis for its framework that is designed "to assist reporting organizations and their stakeholders in articulating and understanding contributions of the reporting organizations to sustainable development" (GRI, 2000; 2002; 2006). While compliance with the Guidelines is entirely voluntary, approximately a third of the corporate responsibility reports produced in 2007 (over 1,000 organizations) use of the GRI framework, with $11 \%$ using the G3 Guidelines (Corporate Register, 2008). In its 2008 survey of the Global Fortune 250 (G250) and the 100 largest companies as measured by revenue in 22 countries (N100), KPMG found that even a higher proportion (75\% of the G250; 70\% of the N100) use the GRI framework (KPMG, 2008).

\section{THE G3 GUIDELINES}

The G3 Guidelines refine the GRI's 2002 (G2 Guidelines) framework for sustainability reporting. Standard disclosures under $G 3$ include three components:

- $\quad$ Strategy and Profile Disclosures set the overall context for reporting and for understanding organizational performance, such as its strategy, profile, governance, and management approach;

- Disclosures on Management Approach cover how an organization addresses a given set of topics in order to provide context for understanding performance in a specific area. 
- Performance Indicators that elicit comparable information on the economic, environmental, and social performance of the organization. (GRI, 2006, p. 19)

In an attempt to enhance comparability and auditability, the G3 Guidelines modify the 97 "key performance indicators" (KPIs) of the G2 framework into 79 performance indicators (GRI, 2007). Fifty of these indicators are considered "core" because the GRI believes them to be of interest to most stakeholders and, consequently, they are "assumed to be material unless deemed otherwise on the basis of the GRI Reporting Principles" (GRI, 2006). Appendix A provides a summary of performance indicators which the GRI recommends be used in communicating an organization's economic, environmental, human rights, and societal performance. One of the most significant aspects of these indicators is that some are quantitative (e.g. LA1: Total workforce by employment type, employment contract, and region) while others are qualitative (e.g. EC7: Procedures for local hiring and proportion of senior management hired from the local community) in nature. Furthermore, the quantitative indicators are expressed in various monetary and non-monetary units of measure. As a result, stakeholders may be talking past one another. As one investment advisor notes, while companies are "busting their guts to tell their sustainability story," shareholders want different information. "They say, don't talk to me about tonnes of $\mathrm{CO}_{2}$. Tell me about earnings per share" (Murphy, 2007).

In addition to these standard disclosures, all G3 reports must contain a GRI Content Index (Element 3.12) to serve as a kind of road-map, alerting readers to where in the report the standard disclosures can be found (GRI, 2006, p. 22). Furthermore, the organization should disclose the level of reporting it has chosen. The levels of reporting range from $\mathrm{C}$ through $\mathrm{A}+$ and replace the G2 Guidelines self-declaration that a report has been prepared "in accordance with" (with a verification statement signed by Board of Directors or CEO) or "with reference to" the GRI Guidelines. The level of reporting chosen can simply be self-declared, verified by an external third party, or checked by the GRI itself. Appendix B contains a description of the differences in the levels of reporting.

In response to criticism of the GRI's one-size-fits-all approach, Sector Supplements have been developed for the financial services, transportation and logistics, mining and metals, public agencies, tour operators, and automotive industries. [See, for example, the GRI Automotive Sector Supplement (GRI, 2004).] These Sector Supplements are not intended as a replacement for the more general $G 3$ framework but do address the more specific issues encountered by companies in particular industries.

\section{METHODOLOGY}

This paper considers whether the reporting in conformity with the GRI G3 Framework adds value for the users of these reports. To do so, this inquiry takes the form of analyzing the content of the published sustainability reports of two well-known companies to compare and contrast the information communicated in these reports. Content analysis is particularly appropriate for sustainability disclosures. Pedrini (2007) uses content analysis to investigate the points of convergence between intellectual capital and corporate responsibility reports prepared under the 2002 Guidelines. Clarkson et al (2008) develop a content analysis index to test the environmental disclosure under the 2002 Guidelines. This study looks to expand beyond the GRI's recommended environmental and intellectual capital disclosures and examines the extent to which companies present the kind of information that the G3Guidelines recommend for all aspects of an organization's TBL performance. Particular attention is paid to differences in the published content between two companies in the same industry - Nike and adidas in the sporting goods industry.

The companies were selected quite intentionally. First of all, Nike and adidas are highly visible companies. Not only are they industry leaders, they have reputations for being good corporate citizens and have received awards and other recognition for their non-financial performance and for their reporting of that performance. Both have prepared their most recent sustainability reports using the G3 Guidelines. Given these common characteristics, one would expect a greater ease of comparability between the companies which is one of the paramount goals of the $G 3$ Guidelines. Indeed, one of the greatest challenges in evaluating the value that is being added by the content in these disclosures is the extraordinarily wide variability in the form of the disclosures. While variability in the content of the disclosures is to be expected due to the differing materiality of issues which a company faces, one would expect 
less variability in content from companies operating in the same industry inasmuch as they face similar challenges to their corporate responsibility.

Some important differences in the company's TBL disclosures would also be expected as a consequence of the company's geographic base. There is a general perception that European-based companies are more sensitive to issues of sustainability than are U.S.-based organizations. Consequently, it will be interesting to see if this perception is confirmed by the reporting of a European company (adidas) as compared and contrasted to that of an American firm (Nike).

\section{NIKE and ADIDAS}

With revenues exceeding $\$ 16$ billion last year, Nike is the world leader in the global sporting goods industry. Despite being named to Ethisphere's list of the world's most ethical companies (Ethisphere, 2007), being recognized as one of the " 100 Best Corporate Citizens" by Business Ethics Magazine as well as one of Fortune Magazine's "100 Best Companies to Work For" (Nike, 2007a, p. 130), Nike has often been target of criticism, particularly for the treatment of workers in the factories in developing countries in which its shoes and apparel are manufactured (Kasky v. Nike, 2000; Klein, 2002; Locke, 2003; Nike v. Kasky, 2003). In response to its critics, Nike established and enforces a Code of Conduct which standardizes its treatment of employees outside the U.S. It was the first company in the industry to disclose its factory base in order to encourage supply chain transparency and continues to disclose the names and locations more than 700 contract factories worldwide producing Nike products (Nike, 2007b). It also posts the company's contract factory auditing tools, providing insight into how the company evaluates and monitors its contract factories for compliance with company standards.

Adidas ranks second in the sporting goods industry with sales over $\$ 13$ billion. The company takes pride in being named as the industry leader in the Dow Jones Sustainability Index (DJSI). Adidas is also included in the FTSE4Good Index, and has been awarded prizes for best sustainability reporting by the German Chamber of Public Accountants. In 2007, the adidas Group was included for the third consecutive time in the list of the "Global 100 Most Sustainable Corporations in the World" (adidas Group, 2008b).

From a corporate responsibility perspective, perhaps the greatest challenge for Nike, adidas, and the global sporting goods and apparel industry is the management of their supply chain. The companies do not manufacturer the shoes, apparel, and equipment they sell under their brand-name. Instead the manufacturing of their products is subcontracted to factories, most of which are located in developing nations. Nike, for example, has only around 24,000 employees, the vast majority of whom work in the United States. All the other workers who actually manufacture the Nike products are employed by independent suppliers. Nike estimates that of the 800,000 workers in its contract supply chain, $80 \%$ are women between the ages of 18 and 24 (Nike, 2007a, p. 16). Due to their historical lack of status and power in their own cultures, these young women are often the most vulnerable to workplace abuses. Adidas has a very similar, if somewhat more geographically dispersed organizational structure (over 31,000 employees in 150 locations (adidas, 2008b, p. 56)) but with its products being made primarily in the same developing countries - and often the same factories - as Nike's products. Because they face similar corporate citizenship challenges, one would expect the companies' sustainability reports to provide similar approaches and similar information to communicate their efforts. The research question at hand is whether the $G 3$ framework facilitates the telling of Nike's and adidas' story.

\section{NIKE'S CORPORATE RESPONSIBILITY REPORT FOR FY 2005-2006}

Since 2001, Nike has produced three stand-alone Corporate Responsibility Reports (Nike, 2001; 2005; 2007a). Its 2004 report garnered awards from SustainAbility's Global Reporting Initiative as the top U.S. Reporter and from Ceres-ACCA North America for Sustainability Reporting (Nike, 2007a). In 2007, Nike produced a 163 page corporate responsibility report (Nike, 2007a) which received high marks for its "creativity in communications" $\left(10^{\text {th }}\right.$ place $)$ and "openness and honesty" ( $2^{\text {nd }}$ place) in the Corporate Register's winners in corporate responsibility reporting (Corporate Register, 2008). Following an increasingly popular practice, the Nike website provides links to more extensive information about the company's activities in the area of corporate social and environmental responsibility (Nike, 2007b). 
In its most recent report (Fiscal Years 2005/2006), Nike set three primary goals in its corporate responsibility efforts - improving worker conditions, creating innovative sustainable products, and effecting social change through sport (Nike, 2007a). The report presents the company's approach to various issues, along with an impressive amount of information on its targets and performance in each area. For example, the report's section on "Considered Design and the Environment" address Nike's efforts to create more environmentally friendly products and operations while "Let Me Play" details the company's approach to addressing social issues through the power of sport.

Nike uses an external report review committee to comment on its report. As the Letter from the report review committee explicitly notes, "the Committee did not function as an assurance provider, since we did not provide any verification or commentary on the accuracy of the data Nike presents in this report" (Nike, 2007b, p. 135). Nevertheless, the review committee does suggest areas for improved sustainability reporting and reviews Nike's response to previous suggestions (Nike, 2007b, p. 128).

While Nike does not specify the $G 3$ reporting level it has chosen, it does states its report was prepared "with reference to the Global Reporting Initiative's third generation of indicators" (Nike, 2007a, p. 131). Consistent with this self-declaration, Nike's report provides an index of compliance to the $G 3$ framework. In this index, Nike notes either where in its report the information recommended by the G3 Guidelines is disclosed or characterizes its non-compliance as (A) information not reported due to a lack of access to appropriate data, (B) information is partially reported, in accordance with systems currently in place and access to data, or (C) the indicator is determined to be not material due to Nike's lack of impact on this issue. Table 1 presents Nike's self-reported compliance with the G3 Framework. Of the nine economic core indicators in the G3 Guidelines, Nike reports on five -3 completely; 2 only partially. In addition, Nike provides some information on 12 of the 30 environmental core indicators ( 9 complete; 3 partial), partial information on 5 of the 14 indicators for labor and decent work (complete information on none), on eight of the nine human rights indicators, on 3 of the 8 indicators for society, and gives partial information on only one of the 9 core indicators for product responsibility. Given this reporting, even though Nike does not itself declare a reporting level, it falls in the B level. As such, the company's use of its AB-C classification is inappropriate. The G3 Guidelines are explicit that reasons for omission are only appropriate for organizations reporting at Level $\mathrm{A}$. They are not permitted for companies reporting at the $\mathrm{B}$ or $\mathrm{C}$ levels.

\section{ADIDAS 2007 SOCIAL \& ENVIRONMENTAL REPORT}

Adidas has longer history of producing social and environmental reports (adidas-Salomon, 2001; 2002; 2003; 2004; 2005; adidas Group, 2006; 2007). For 2007, adidas provides both a 24- page hard-copy sustainability report (adidas Group, 2008a) and an on-line version (adidas Group, 2008b) which provides links to more extensive and detailed measures of performance and other information relating to its efforts to promote sustainable development.

The adidas Social \& Environmental Report for 2007 addresses most of the same issues as Nike's Corporate Responsibility Report - i.e., management of its supply chain, environmental impact, employees, and community relations. However, both the content and style of the report are quite different from Nike's. Adidas frequently utilizes short case studies and other narrative techniques. For example, the company's approach to labor practices and decent work is presented in the form of an interview with the company's chief human resource officer, Matthias Melassa (adidas Group, 2008a, p. 9). Discussion of its environmental policies takes the form of a question-andanswer section (adidas Group, 2008, p. 18). As is the case with the Nike report, adidas presents a great deal of quantitative information such as the gender breakdown and average age of its workforce, employee turnover, its energy usage, the number and results of its audits of its subcontractors. Very little of this information is expressed in the same units of measure as Nike's. Consequently, a comparison of relative performance is difficult, if not impossible.

Like Nike, adidas does not have external verification of its report. However, in contrast to Nike, adidas does not have any overall external review of its report. The company's position is clear: 
While we strive to continuously improve our reporting systems for supplier monitoring data, we feel that much of this data, in particular data on labour conditions, is not always verifiable in a standardised way. At this stage therefore we do not feel that a report verification would add value. We do, however, believe that independent verification of workplace conditions and of the processes and monitoring approaches we adopt in our compliance programme is important. For this reason the report does contain information that is subjected to an annual review by the Fair Labor Association. We also refer to data verified when supplier factories or our own facilities were certified to ISO, EMAS and OSHAS standards (adidas Group, 2008c).

Adidas is quite candid about the degree with which it complies with the G3 Framework, choosing only to report at "Level C":

For the 2007 report we have chosen level C reporting for the following reasons: we have gone through a careful and rigorous self-critical process of analysis of where our report completely meets the relevant indicators, we acknowledge that there are still gaps in our reporting. However it is part of our approach to transparency and credible communication not to hide these gaps to our stakeholders by superficially addressing issues in the report, which are not backed by effective policies and programmes.

While the GRI guidelines are a useful benchmark for report readers, we believe they do not fully take into account the nature of the sporting goods industry, where the impacts of supply chain management and their specific challenges outweigh the direct social and environmental impacts of the companies themselves (adidas Group, 2008c).

Given this admission of the "gaps in our reporting," it is not surprising that adidas compliance with the G3 Guidelines is spotty at best. Unlike Nike's content index, adidas does not characterize its non-compliance along an A-B-C scale. As noted above, this is entirely appropriate since the $G 3$ standards do not permit reasons for omissions for companies reporting at Level C. The adidas index merely reports where information about a particular GRI core performance indicator is disclosed, if at all. As Table 1 summarizes, of the nine economic core indicators in the $G 3$ Guidelines, adidas reports on only one. The company provides information on only 2 of the 30 environmental core indicators, on 2 of the 14 indicators for labor and decent work, on 4 of the 9 human rights indicators, on none of the 8 indicators for society, and on 2 of the 9 core indicators for product responsibility. Relative to Nike or indeed to any other organization, adidas' compliance with the G3 Guidelines is minimal at best. One wonders why the company bothers to go through the motions of referencing the G3 Guidelines at all.

\section{NIKE, ADIDAS \& THE G3 FRAMEWORK}

An analysis of the content of the two reports reveals disturbing inconsistencies in the way in which economic, social, and environmental performance is disclosed. Given their common critical corporate challenge, of particular interest is the difference in the way in which each company communicates its efforts to manage its supply chain. The locations of the companies suppliers is remarkably similar (adidas, 2008a, p. 62-63; Nike, 2007a, p. 25). Indeed, both companies often use the same factories. Despite this, the metrics used to measure performance are noncomparable. For example, adidas has created a KPI (Key Performance Indicator) consisting of six units of measure (adidas, 2008a, p. 36). While the company reports the average score of compliance in each of the units of measure, there is no way to interpret these data. Nike has a seemingly similar system of auditing the compliance of its suppliers with company policies but it reports the results of this compliance in very different terms than does adidas (Nike, 2007a, pp. 30-32). In short, there is no way to conclude which company is doing a better job of managing its supply chain.

Differences in how performance is measured exist in the reporting of environmental and workplace dimensions as well. For example, in communicating information about its workforce, adidas not only has a gender breakdown but also discloses average age, average tenure in position, turnover rates, and number of hours of training per employee (adidas, 2008b, p. 70). Nike, on the other hand, discloses the breakdown based upon gender and ethnicity but does not disclose any of the other information that adidas does about its employees (Nike, 2007b, p. 100). One would be hard pressed to reach a conclusion about whether the two companies' workforces and employment practices are similar or different. 
After analyzing the content of the most recent Nike and adidas sustainability reports, it would seem that the G3 Guidelines are not achieving their intended results. Rather than presenting common denominators for comparison of the two companies' economic, environmental, and social performance, the disparity in the amounts and types of core performance indicators presented by Nike and adidas make any comparison between the two companies meaningless. This is not necessarily to fault the G3 Guidelines themselves. Rather it may simply illustrate an inconsistent application of the guidelines which is a direct result of the voluntary nature of their use. A better result would be expected if the companies had at least used the same level of reporting. However, given the differences in the way in which the common indicators that both companies reported, even the same level of reporting would not solve the problem of incomparability.

\section{CONCLUSION}

You've heard it all before. Someone reviews a corporate social responsibility report and complains that there are too many pictures of rainbows and smiling children. There's not enough hard data. It's clearly a marketing piece. On the other hand, overly-analytical reports are described as "dense" and can be overwhelming to anyone but the report writer. You hear things like, I'm not a financial analyst, I'm just trying to understand if your company is "green" or not. The dilemma for companies is whether to make a CSR report accessible to a broad group of stakeholders (i.e. rainbows) or focus mainly on progress against key indicators (i.e. return on investment). (Hausman, 2008).

There seems to always be an abundance of rainbows in sustainability reporting. However, the $G 3$ Guidelines are intended to insure that consistent, comparable, hard data are also provided. Given the early stage of development of reporting under the GRI G3 Guidelines, it is premature to be too critical of the value that is being added by such reporting. Moreover, there will probably always be difficulty of interpreting core performance indicators even when they are consistently disclosed. As one survey of sustainability reports concludes:

At the same time, the problem may arise from the lack of an established means of assessing sustainability information in reports. It might then be said that the reports provide "too much information, too little meaning" (KPMG \& SustainAbility, 2008, p. 29).

To complicate this analysis, no standard report structure has emerged. One consequence of this is that the reader of sustainability reports must sift through interviews, case studies, and other narrative techniques, dodging rainbows along the way, in order to try to find information that may not be reported at all. Some of these difficulties are mitigated by the $G 3$ requirement that companies provide a index of how a particular report complies with the $G 3$ Guidelines and where particular information is located in the report. However, as one study concludes, "it appears that many tend to 'retrofit' the GRI guidelines, i.e., first develop the report and then cross-check with the guidelines to produce the GRI contents index" (Corporate Register, 2008, p. 31). It is not surprising that in a 2008 survey of 2,279 respondents worldwide, 452 did not read sustainability reports because they thought there were better ways to get information (KPMG \& SustainAbility, 2008). In this same survey, 25\% of the respondents felt that the most significant issues were entirely absent from the reports, with a slight majority feeling the most significant issues weren't treated with enough detail. Those who participated in the survey felt the most significant omission in sustainability reports was an acknowledgement of the company's failures.

Nevertheless, sustainability reporting continues to experience impressive gains. KPMG's 2008 International Survey on Corporate Responsibility Reporting found that 74 percent of the top 100 U.S. companies published corporate responsibility information in 2008, either as part of their annual financial report or as a separate document. This was an increase from the 37 percent of top U.S. companies that KPMG surveyed in 2005. An even higher percentage of top international firms are reporting on their environmental and social performance with 80 percent of the Global Fortune 250 companies now releasing this information (KPMG, 2008).

Even with the growing acceptance of the GRI framework as a common ground for TBL reporting, the disparity in how and what is being reported continues to be frustrating. At best, there is currently a benchmarking of content of TBL reports, not a benchmarking of actual economic, environmental, and social performance. Even the ticking off of content is troublesome because of the widely differing types and amounts of information being 
reported. In partnership with other organizations, the GRI has analyzed the reporting of human rights, labor practices, and community impact. For human rights, only $7 \%$ of the companies surveyed provided full conformity with the GRI core performance indicators (GRI \& Roberts, 2008); only $11 \%$ followed the GRI protocol for society disclosures (GRI, University of Hong Kong \& CSR Asia, 2008). In short, this study's analysis of the Nike and adidas reports is very much in line with the overall state of sustainability reporting.

Does the Global Reporting Initiative add value to the reporting of a company's economic, environmental, and social performance? If one of the purposes of the G3 Guidelines is to allow us to compare and contrast companies and at the end of our analysis to be able to conclude that Nike's environmental performance is better than adidas' or that adidas' social performance is better than Nike's, then the Guidelines have failed. At least at this stage, we clearly have a long way to go before the equivalent of GAAP for sustainability reporting is established.

Table 1: Analysis of G3 Framework Content Index

\begin{tabular}{|c|c|c|}
\hline Economic & Nike & adidas \\
\hline EC1 & $\mathrm{Y}$ & $\mathrm{Y}$ \\
\hline $\mathrm{EC} 2$ & $\mathrm{Y}$ & NR \\
\hline EC3 & $\mathrm{Y}$ & NR \\
\hline $\mathrm{EC} 4$ & NR & NR \\
\hline EC5 & NR & NR \\
\hline EC6 & NR & NR \\
\hline EC7 & NR & NR \\
\hline EC8 & $\mathrm{P}$ & NR \\
\hline EC9 & $\mathrm{P}$ & NR \\
\hline Environmental & Nike & adidas \\
\hline EN1 & $\mathrm{Y}$ & NR \\
\hline EN2 & $\mathrm{Y}$ & NR \\
\hline EN3 & NR & NR \\
\hline EN4 & $\mathrm{Y}$ & NR \\
\hline EN5 & $\mathrm{Y}$ & NR \\
\hline EN6 & $\mathrm{P}$ & NR \\
\hline EN7 & Y & NR \\
\hline EN8 & $\mathrm{P}$ & NR \\
\hline EN9 & NR & NR \\
\hline EN10 & NR & NR \\
\hline EN11 & NM & NR \\
\hline EN12 & NM & NR \\
\hline EN13 & NM & NR \\
\hline EN14 & NM & NR \\
\hline EN15 & NM & NR \\
\hline EN16 & NR & NR \\
\hline EN17 & NR & $\mathrm{Y}$ \\
\hline EN18 & NR & NR \\
\hline EN19 & NM & NR \\
\hline EN20 & NM & NR \\
\hline EN21 & $\mathrm{P}$ & NR \\
\hline EN22 & $\mathrm{Y}$ & NR \\
\hline EN23 & NM & NR \\
\hline EN24 & NR & NR \\
\hline EN25 & NR & NR \\
\hline EN26 & $\mathrm{Y}$ & $\mathrm{Y}$ \\
\hline EN27 & $\mathrm{Y}$ & NR \\
\hline EN28 & $\mathrm{NM}$ & NR \\
\hline EN29 & $\mathrm{Y}$ & NR \\
\hline EN30 & NR & NR \\
\hline
\end{tabular}




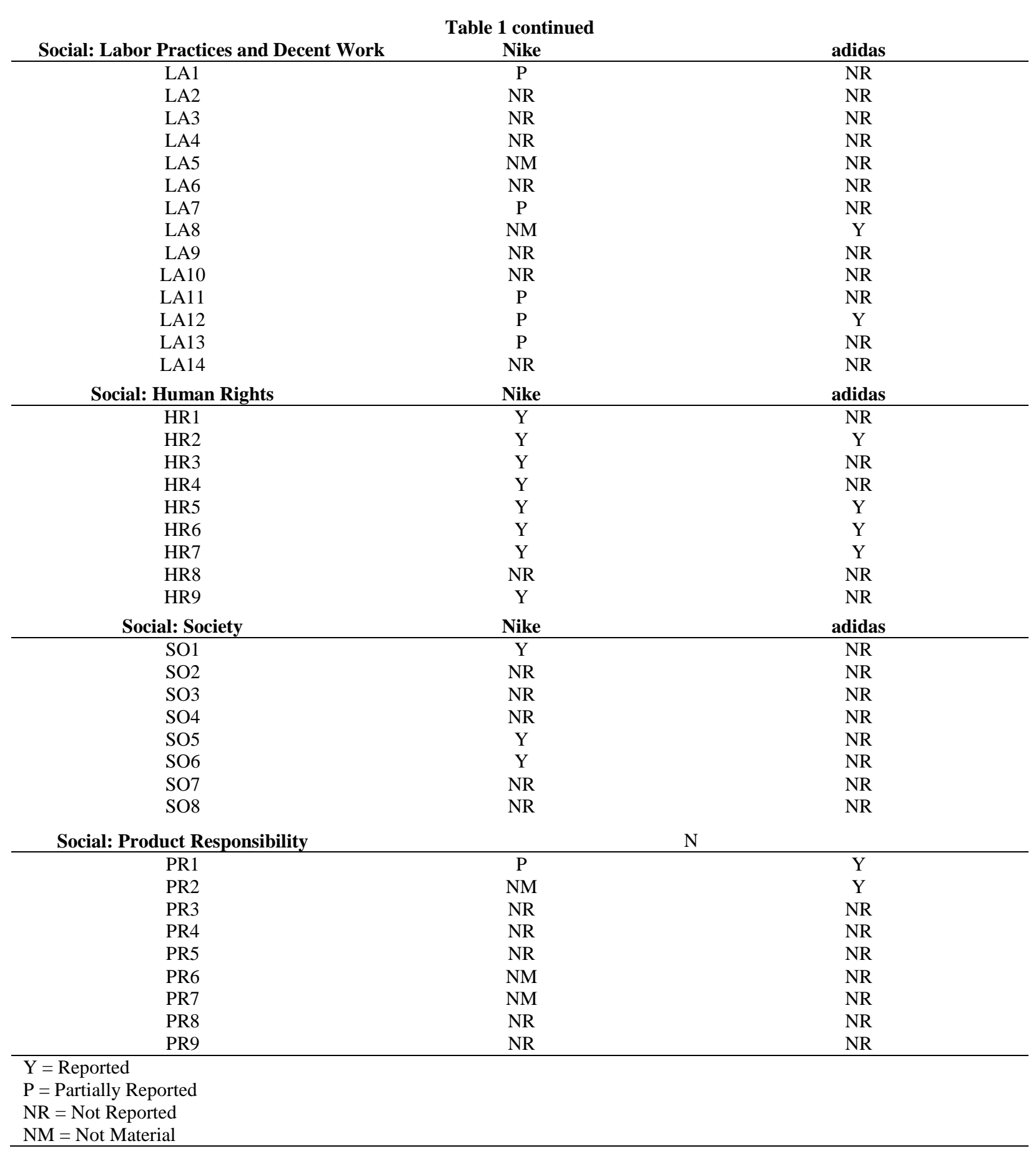

\section{AUTHOR INFORMATION}

W. Richard Sherman, J.D., LL.M., C.P.A., is a Professor of Accounting in the Saint Joseph's University's Erivan K. Haub School of Business in Philadelphia, PA. Recipient of numerous awards for teaching excellence, including the prestigious Christian and Mary Lindback Foundation Award for Distinguished Teaching, Professor Sherman has published over 50 articles in academic and professional journals. His research spans issues in accounting education, tax, and sustainability reporting. 


\section{REFERENCES}

1. adidas Group (2006). Connected by football: 2005 social and environmental report. Accessed on 20 Nov. 08 at http://www.adidasgroup.com/en/sustainability/_downloads/social_and_environmental_reports/connected_by_football_social_ and_environmental_report_2005.pdf.

2. $\quad$ adidas Group (2007). The integration of our social and environmental programmes in 2006. Accessed on 20 Nov. 08 at http://www.adidasgroup.com/en/sustainability/_downloads/social_and_environmental_reports/Questions_and_Answers_book let_2006_English.pdf

3. adidas Group (2008a). Giving 110\%: our effort to be a responsible business in 2007. Accessed on 20 Nov. 08 at http://www.adidas-group.com/en/SER2007/pdf/adidas_SER2007 report.pdf.

4. $\quad$ adidas Group. (2008b). Striving to improve performance: 2007 corporate responsibilityreport. (Web version). Accessed on 20 Nov. 08 at http://www.adidas-group.com/en/SER2007/

5. adidas Group. (2008c). GRI index. Accessed on 20 Nov. 08 at http://www.adidasgroup.com/en/SER2007/gri index.asp.

6. adidas Group. (2008d). Statement on verification. Accessed on 20 Nov. 08 at http://www.adidasgroup.com/en/sustainability/reporting/statement_on_verification/default.asp

7. adidas-Salomon (2001). Our world: social and environmental report 2000. Accessed on 20 Nov. 08 at http://www.adidas-group.com/en/sustainability/_downloads/social_environmental_report_2000_e.pdf

8. $\quad$ adidas-Salomon (2002). Clearer: social and environmental report 2001. Accessed on 20 Nov. 08 at http://www.adidasgroup.com/en/sustainability/_downloads/Clearer_Social_and_Environmental_Report_2001.pdf

9. adidas-Salomon (2003). Behind our brand: social and environmental report 2002. Accessed on 20 Nov. 08 at http://www.adidas-group.com/en/sustainability/_downloads/adidas_Salomon_SER_2002.pdf

10. adidas-Salomon (2004). Staying focused: social and environmental report 2003. Accessed on 20 Nov. 08 at http://www.adidasgroup.com/en/sustainability/_downloads/social_and_environmental_reports/staying_focused_social_and_e nvironmental report 2003 1.pdf

11. adidas-Salomon (2005). Taking on the challenges, wherever we operate: social and environmental report 2004. Accessed on 20 Nov. 08 at http://www.adidas-

group.com/en/sustainability/_downloads/social_and_environmental_reports/taking_on_the_challenges_soci al_and_environmental_report_2004.pdf.

12. Clarkson, P.M., Y. Li, G. D. Richardson \& F. P. Vasvari (2008). Revisiting the relation between environmental performance and environmental disclosure: an empirical analysis. Accounting, Organizations and Society. Volume 33, Issues 4-5, May-July 2008, pp. 303-327.

13. Corporate Register (2008). CR reporting awards '07: global winners and reporting trends. Accessed on 20 Nov. 08 at http://www.corporateregister.com/crra_last/

14. Elkington, J. (1997). Cannibals with forks: the triple bottom line of the $21^{\text {st }}$ century business. Capstone, Oxford.

15. Elkington, J. (1999). Triple bottom-line reporting: looking for balance. Australian CPA, 18-21.

16. Ethisphere (2007). World's most ethical companies. Accessed on 20 Nov. 08 at http://ethisphere.com/2007worlds-most-ethical-companies/.

17. Global Reporting Initiative (GRI, 2000). Sustainability reporting guidelines on economic, environmental, and social performance. Boston: Coalition for Environmentally Responsible Economies.

18. Global Reporting Initiative (GRI, 2002). Sustainability reporting guidelines. Accessed on 20 Nov. 08 at http://www.globalreporting.org.

19. Global Reporting Initiative (GRI, 2004). GRI automotive sector supplement - Pilot version 1.0. Accessed on 20 Nov. 08 at http://www.globalreporting.org/NR/rdonlyres/70611BE2-F097-4550-AEC7D93B1A858D49/0/AutomotiveSectorSupplementPilot.pdf

20. Global Reporting Initiative (GRI, 2006). Sustainability reporting G3 guidelines. http://www.globalreporting.org/NR/rdonlyres/ED9E9B36-AB54-4DE1-BFF25F735235CA44/0/G3_GuidelinesENU.pdf 
21. Global Reporting Initiative (GRI, 2007). Making the switch. Accessed on 20 Nov. 08 at http://www.globalreporting.org/NR/rdonlyres/8F4781CA-BB96-4B68-8FBDA1CC3AA0E353/450/MakingtheSwitch.pdf.

22. Global Reporting Initiative (GRI, 2008a). About the GRI. Accessed on 20 Nov. 08 at http://www.globalreporting.org/AboutGRI/

23. Global Reporting Initiative (GRI, 2008b). Everything you need to know about the G3 Guidelines - past, present, and future.

24. Hausman, A. (2008). CSR Reporting: Rainbows Versus ROI. Accessed on 20 Nov. 08 at http://www.environmentalleader.com/2008/03/13/csr-reporting-rainbows-versus-roi/.

25. Kasky v. Nike (2000). 93 Cal Rptr 2d 854.

26. Klein, N. (2002). No logo. New York: Picador Press.

27. KPMG (2008). International Survey of Corporate Responsibility Reporting 2008. Accessed on 20 Nov. 08 at https://www.kpmg.com/SiteCollectionDocuments/International-corporate-responsibility-survey-2008.pdf

28. KPMG \& SustainAbility (2008). Count me in: the reader's take on sustainability reporting. Accessed on 20 Nov. 08 at http://www.globalreporting.org/NR/rdonlyres/3F57ACC8-60D0-48F0-AF28527F85A2A4B4/0/CountMeIn.pdf

29. Locke, R. M. (2003). The promise and perils of globalization: the case of Nike. In Thomas A. Kochan and Richard Schmalensee (eds): Management: Inventing and delivering its future. Cambridge, MA, MIT Press, pp. 39-70.

30. $\quad$ Murphy, S. (1997). Financial times, Special sustainability report, October 12, 2007, p. 9.

31. Nike (2002). Corporate responsibility report - FY 01. Accessed on 20 Nov. 08 at http://www.nikeresponsibility.com/pdfs/color/Nike_FY01_CR_report.pdf

32. Nike (2005). Corporate responsibility report - FY 04. Accessed on 20 Nov. 08 at http://www.nikeresponsibility.com/pdfs/color/Nike_FY04_CR_report.pdf

33. Nike (2007a). Innovate for a better world: Nike FY 05/06 corporate responsibility report. Accessed on 20 Nov. 08 at http://www.nikeresponsibility.com/pdfs/color/Nike_FY05_06_CR_Report_C.pdf

34. Nike (2007b). Innovate for a better world. (Web version). Accessed on 20 Nov. 08 at http://www.nikeresponsibility.com/\#home/.

35. Nike (2008). Accessed on 20 Nov. 08 at http://www.nikeresponsibility.com

36. Nike v. Kasky (2003). Nike, Inc. et al., Petitioners v. Marc Kasky, Respondent, 123 S. Ct. 2554 (No. $02-$ 575).

37. Pedrini, M. (2007). Human capital convergences in intellectual capital and sustainability reports. Journal of Intellectual Capital. Vol. 8, Issue 2; pp. 346. Retrieved May 18, 2008, from ABI/INFORM

Global database. (Document ID: 1344405941).

\section{APPENDIX A: KEY PERFORMANCE INDICATORS-GRI G3 FRAMEWORK}

\section{Economic}

EC1: Direct economic value-generated and distributed, including revenues, operating costs, employee compensation, donations and other community investments, retained earnings and payments to capital providers and customers

EC2: Financial implications and other risks and opportunities for the organization's activities due to climate change

EC3: Coverage of the organization's defined benefit plan obligations

EC4: Significant financial assistance received from the government

EC5: Range of ratios of standard entry level wage compared to local minimum wage at significant locations of operation

EC6: Policy, practices and proportion of spending on locally-based suppliers at significant locations of operations

EC7: Procedures for local hiring and proportion of senior management hired from the local community

EC8: Development and impact of infrastructure investments and services provided primarily for public benefit through commercial, in-kind, or pro bono engagement

EC9: Understanding and describing significant indirect economic impacts, including the extent of impacts 


\section{Environmental}

EN1: Materials used by weight or volume

EN2: Percentage of materials used that are recycled input materials

EN3: Direct energy consumption by primary energy source

EN4: Indirect energy consumption by primary source

EN5: Energy saved due to conservation and efficiency improvements

EN6: Initiatives to provide energy-efficient or renewable energy-based products and services and reductions in energy requirements as a result of these initiatives

EN7: Initiatives to reduce indirect energy consumption and reductions achieved

EN8: Total water withdrawal by source

EN9: Water sources significantly affected by withdrawal of water

EN10: Percentage and total volume of water recycled and reused

EN11: Location and size of land owned, leased, managed in, or adjacent to protected areas and areas of high biodiversity value outside protected areas

EN12: Descriptions of significant impacts of activities, products, and services on biodiversity in protected areas and areas of high biodiversity value outside protected areas

EN13: Habitats protected or restored

EN14: Strategies, current actions, and future plans for managing impacts on biodiversity

EN15: Number of IUCN Red List species and national list species with habitats in areas affected by operations, by level of extinction risk

EN16: Total direct and indirect greenhouse gas emissions by weight

EN17: Other relevant indirect greenhouse gas emissions by weight

EN18: Initiatives to reduce greenhouse gas emissions and reductions achieved

EN19: Emissions of ozone-depleting substances by weight

EN20: NOx, Sox, and other significant air emissions by type and weight

EN21: Total water discharge by quality and destination

EN22: Total weight of waste by type and disposal method

EN23: Total number and volume of significant spills

EN24: Weight of transported, imported, or treated hazardous waste and percentage of transported waste shipped internationally

EN25: Identity, size, protected status, and biodiversity value of water bodies and related habitats significantly affected by the reporting organization's discharges of water and runoff

EN26: Initiatives to mitigate environmental impacts of products and services, and the extent of impact mitigation

EN27: Percentage of products sold and their packaging materials that are reclaimed by category

EN28: Monetary value of significant fines and total number of non-monetary sanctions for non-compliance with environmental laws and regulations

EN 29: Significant environmental impacts of transporting products and other goods and materials used for the organization's operations, and transporting members of the workforce

EN30: Total environmental protection expenditures and investments by type

\section{Society}

SO1: Nature, scope, and effectiveness of any programs and practices that assess and manage the impacts of operations on communities, including entering, operating, and exiting

SO2: Percentage and total number of business units analyzed for risks related to corruption

SO3: Percentage of employees trained in the organization's anti-corruption policies and procedures

SO4: Actions taken in response to incidents of corruption

SO5: Public policy positions and participation in public policy development and lobbying

SO6: Total value of financial and in-kind contributions to political parties, politicians, and related institution by country

SO7: Total number of legal actions for anti-competitive behavior, anti-trust, and monopoly practices and their outcomes

SO8: Monetary value of significant fines and total number of non-monetary sanctions for non-compliance with laws and regulations 


\section{Human Rights}

HR1: Percentage and total number of significant investment agreements that include human rights clauses or that have undergone human rights screening

HR2: Percentage of significant suppliers that have undergone screening on human rights and actions taken

HR4: Total number of incidents of discrimination and actions taken

HR5: Operations identified in which the right to exercise freedom of association and collective bargaining may be at significant risk and actions taken to support these rights

HR6: Operations identified as having significant risk for incidents of child labor, and measures taken to contribute to the elimination of child labor

HR7: Operations identified as having significant risk for incidents of compulsory labor, and measures taken to contribute to the elimination of compulsory labor

HR8: Percentage of security personnel trained in the organization's policies and procedures concerning aspects of human rights that are relevant to operations.

HR9: Total number of incidents of violations involving rights of indigenous people and actions taken.

\section{Labor Practices \& Decent Work}

LA1: Total workforce by employment type, employment contract, and region

LA2: Total number and rate of employee turnover by age group, gender, and region

LA3: Benefits provided to full-time employees that are not provided to temporary or part-time employees

LA4: Percentage of employees covered by collective bargaining agreements

LA5: Minimum notice period(s) regarding operational chances

LA6: Percentage of total workforce represented in formal joint management-worker health and safety committees that help monitor and advise on occupational health and safety programs

LA7: Rates of injury, occupational diseases, lost days, and absenteeism, and number of workforce fatalities by region

LA8: Education, counseling, prevention, and risk-control programs in place to assist workforce members, their families, or community members regarding serious diseases

LA9: Health and safety topics covered in formal agreements with trade unions

LA 10: Average hours of training per year per employee by employee category

LA 11: Programs for skills management and lifelong learning that support continued employability of employees and assist them in managing career endings

LA12: Percentage of employees receiving regular performance and career development reviews

LA13: Composition of governance bodies and breakdown of employees per category according to gender, age group, minority group membership, and other indicators of diversity

LA14: Ratio of basic salary of men to women by employee category

\section{Product Responsibility}

PR1: Life cycle stages in which health and safety impacts of products and services are assessed for improvement, and percentage of significant products and service categories subject to such procedures

PR2: Total number of incidents of non-compliance with regulations and voluntary codes concerning health and safety impacts of products and services during their life cycle, and their outcomes

PR3: Type of product and service information required by procedures and percentage of significant products and service categories subject to such procedures

PR4: Total number of incidents of non-compliance with regulations and voluntary codes concerning product and service information and labeling, and their outcomes

PR5: Practices related to customer satisfaction, including the results of surveys measuring customer satisfaction

PR6: Programs for adherence to laws, standards, and voluntary codes concerning marketing communications, including advertising, promotion, and sponsorship

PR7: Total number of incidents of non-compliance with regulations and voluntary codes concerning marketing communications, including advertising, promotion, and sponsorship by type or outcome

PR8: Total number of substantiated complaints regarding breaches of customer privacy and losses of customer data PR9: Monetary value of significant fines for noncompliance with laws and regulations concerning the provision and use of products and services 


\section{APPENDIX B: LEVELS OF REPORTING}

\section{For Application Level A:}

Profile Disclosures: All.

Management Approach Disclosures: All.

Performance Indicators: Each core indicator through the use of the Materiality Reporting Principle.

Reasons for omissions are required in case of not reporting.

\section{For Application Level B:}

Profile Disclosures: All.

Management Approach Disclosures: All.

Performance Indicators: At minimum 20 Performance Indicators, either core or additional, including at least one from each Indicator Category (Economic, Environmental, Human Rights, Labor, Society, and Product Responsibility).

No reasons for omission possible.

\section{For Application Level C:}

Profile Disclosures: A selection.

Management Approach Disclosures: None.

Performance Indicators: At minimum 10 Performance Indicators, either core or additional, including at least one of each Indicator Dimension (Economic, Environmental, Human Rights, Labor, Society, and Product Responsibility). No reasons for omission possible.

The "+" level means that the some external assurance has been provided. The assurance statement must be included with the report.

Source: GRI, 2008b. 
NOTES 